\title{
JOB SATISFACTION: ANALYSIS OF SOCIO-DEMOGRAPHIC DATA RELATED TO JOB SATISFACTION AMONG TEACHERS IN THE VIDZEME REGION
}

\author{
Aivis Dombrovskis \\ Private practice in Psychology, Latvia
}

\begin{abstract}
This study analyses the socio-demographic factors of a group of teachers and school headmasters and their job satisfaction. It explores potential correlations and links between socio-demographic factors, the subjects which they teach, their role at the educational institution and the level of job satisfaction. The data were collected from 128 female respondents $(N=128)$ from nine regional communities in the Vidzeme region of Latvia. Respondents were between 22 and 73, with an average age of 49. They were divided into five categories on the basis of age. There were also eight categories for subjects, teaching levels and the performed roles - the arts, the humanities, the social sciences, other sciences, preschool teachers (with students aged 1-7), primary school teachers (7-10), elementary school teachers (7-16) and headmasters. The study shows that job satisfaction among teachers is closely linked to the issue of whether they do or do not have children. Socio-demographic indicators such as partnership, the number of marriages, the number of marriages of their parents, and the existence of siblings - these indicated links, but not statistically significant ones in relation to the job satisfaction of teachers. The Likert scale was used to measure job satisfaction. The collected data were analysed with non-parametric methods.
\end{abstract}

Keywords: job satisfaction; educators; pedagogue; socio-demographic data of pedagogues; subject teachers; Vidzeme region.

\section{Introduction}

Schools and systems of education undergo constant changes that relate to new scientific discoveries, new educational paradigms, as well as the overall economic market, development and improvement to ensure the best possible quality of education for students. The E-class Internet site: "There are active efforts at this time not just in Latvia, but all over the world, to turn the ship of the educational system into a more modern direction, mostly in terms of the content of learning. It can be said that education is currently undergoing the most important paradigm shift during the past 100 years" (E-klase, 2015). As an organisation, a school is usually seen as a special entity that is not linked to the business world. It must be noted, however, that schools are organisations which are equal business partners for other business organisations, albeit with their own 
specifics. Processes related to schools provide services (teachers) and buy services (students and their parents). Schools also involve competition, because parents can choose the school to which they will send their children. They also think about the criteria for that choice. These are subjective criteria, but parents usually communicate among themselves so as to discuss the reputation of schools. This most often has to do with student achievements at educational Olympiads, as well as with school results. Persevica has argued that much attention is focused on the quality of education, but not enough attention is focused on human resources which ensure this quality (Peršēvica, 2013). Psychologist Zegele, for her part, argues that an important aspect of the quality of work is the satisfaction of employees with their work: "Employees with a higher level of satisfaction with their work care more about the quality of their work, are more productive, are more loyal to the organisation, and keep their jobs for a longer time, as opposed to looking for a new job" (Zegele, 2008, p.34). This shows that the quality of a teacher's work depends very importantly on the teacher's satisfaction with the job. Persevica's dissertation included research about links between the satisfaction of pedagogues with tier work and the quality of education, finding that interpersonal relationships are a key factor in increasing job satisfaction and in ensuring the quality of education (Peršēvica, 2013). It is universally known that the first interpersonal relationships of a person emerge in the family when an infant first makes contacts with parents or other family members. This continues to the time when interpersonal relationships start to expand and become richer with relationships with people outside the family. Arvey and colleagues have studied twins to see how satisfied they are with work, finding that this partly depends on genetic factors (Arvey, Bouchard, Segal \& Abraham, 1989). Persevica, in turn, argues that it is necessary to take a more in-depth look at how demographic factors influence the quality of work (Peršēvica, 2013). She surveyed high school teachers to find out how satisfied they were with their work (Peršēvica, 2013). This issue does not relate just to the pedagogical sector. It is an updated problem for the entire European Union. The European Commission released a press release to note that on April 7, 2014, the European Agency for Safety and Health at Work (EU-OSHA) launched a campaign, "Healthy Workplaces Manage Stress," the aim being to increase the level of information about psychological, physical and social risks that relate to stress at work (Eiropas komisija, 2014). According to data from the Latvian Central Statistical Board, 21,789 teachers were working for general education schools in Latvia at the beginning of the 2019 school year (Centrālās Statistikas Pārvaldes datu bāze, 2020).

Goal of the research: To examine links between the satisfaction of teachers with their work and socio-demographic indicators. 
Research questions:

1) How satisfied are teachers from the preschool to the elementary school level with their work?

2) What are links between this level of satisfaction and the sociodemographic indicators of the teachers?

\section{The Research}

\section{Literature review}

According to Lim, satisfaction with work is a driving force to ensure that employees are more productive, innovative and focused on the provision of highquality services (Lim, 2007). The Cambridge Dictionary defines the concept of job satisfaction as such: "The feeling of pleasure and achievement that you experience in your job when you know that your work is worth doing, or the degree to which your work gives you this feeling" (Cambridge Dictionary, 2020). Locke has argued that job satisfaction is a relationship between expectations and that which happens, i.e., considering what a person expects from the job and the things that are received from the job (Locke, 1976). Graham, for his part, has argued that job satisfaction is a measurement of one's total feeling and attitudes towards one's job (Graham, 1982). Hoppock has offered a broader definition, arguing that job satisfaction is any combination of psychological, physiological and environmental circumstances that cause a person truthfully to say I am satisfied with my job (Hoppock, 1935).

Vroom focuses more on the role of an employee at work, arguing that job satisfaction speaks to affective orientations on the part of individuals toward work roles which they are presently occupying (Vroom, 1964). Vroom further emphasises the individual when it comes to job satisfaction, as opposed to some random and impersonal employee.

Pool points out that a person is a dynamic organisation with individual characteristics (Pool, 1998). Mullins, for his part, argues that job satisfaction is a complex and multi-faceted concept which will be different for each person and have a different content. Mullins also argues that job satisfaction usually relates to motivation, but also noting that the link between job satisfaction and motivation is not clear. Mullins insists that satisfaction is not the same as motivation, arguing that job satisfaction may be more an issue of a person's attitude and internal situation. For instance, that may relate to personal feelings about qualitative and quantitative achievements (Mullins, 2005). Zembylas and Papanastasiou have examined the job satisfaction of teachers and found that this is basically based on how effective relations between the duties of schoolchildren and the duties of schoolteachers are Zembylas \& Papanastasiou, 2006). 
Hughes, et al., in turn, argue that it is important to note that job satisfaction does not have to do with how well an employee feels about the work that has been done and how much effort the employee has invested. Instead, the issue is how much the employee enjoys the job (Hughes et al., 2006). These various theories show that job satisfaction is based on personal factors such as heredity (Arvey, Bouchard, Segal \& Abraham, 1989), as well as external environmental factors (Hoppock, 1935).

Spector (Spector, 1997) divided job satisfaction factors into two categories environmental and individual. Individual factors include psychological factors such as personality, attitude, behaviour, while demographic factors speak to age, gender, educational levels, etc. (Rauf, 2012; Ramanaidu, 2011). Other researchers have differentiated between cognitive and affective categories (Organ and Near, 1985). Ebru (1995), as well as other researchers (Dewar \& Werbel, 1979; Parasuraman, 1982), argue that personal factors such as experience and age will have an effect on job satisfaction.

Suma and Lesha (Suma \& Lesha, 2013) identify two aspects of job satisfaction - satisfaction with facts and general satisfaction. Judge and Watanab for their part, argue that job satisfaction is closely linked to overall satisfaction with life (Judge \& Watanab, 1994).

\section{Methodology}

\section{Cohort}

The research cohort represents $128(\mathrm{~N}=128)$ teachers from 22 to 73 years of age (Mean=48.97; Median=50.00). Research data were collected at a teacher conference involving teachers from the Amata, Priekuli, Ligatne, Pargauja, Rauna, Vecpiebalga, Jaunpiebalga and Cesis administrative districts. 237 questionnaires were filled out, and six of them were only partly completed and were thus destroyed. Of the utile questionnaires, 128 were filled out by women, and three were filled out by men. Because the number of questionnaires from men was insufficient to analyse the results from the gender perspective, these questionnaires, too, were removed from the cohort, leaving only the ones that had been filled out by women for further consideration.

The cohort's socio-demographic indicators

Because the research is focused on socio-demographic indicators, a wide range of them were included in the questionnaire. They are summarised in Table 1.

Data about socio-demographic indicators (Table 1 ) shows that the age varies from 22 to 73, which is why five age categories were identified, as opposed to the initial 35 categories. That made data processing easier. There was a similar approach toward identifying subjects which pedagogues have studied, and these 
are grouped in accordance with Cabinet of Ministers regulations on educational classifications (Izglīîibas klasifikācija, 2017) - chemistry, biology, etc., and math are grouped under "Sciences." The same Cabinet of Ministers regulations were used to group topics under "Teaching Subject Group," although this was insufficient in that some teachers teach several topics that should be put into two groups (mathematics and language); instead they were put in a single group. A teacher who teaches maths, Latvian and crafts is listed under "Sciences," empirically assuming that maths are a leading scientific topic which teachers teach. This grouping of topics was necessary because many teachers teach several unrelated subjects.

Table 1 The Socio-demographic Indicators of Respondents

\begin{tabular}{|c|c|c|c|}
\hline \multicolumn{2}{|c|}{ Soc.Dem.Factors Soc.Dem. Sub- factors } & Frequency & Percent \% \\
\hline \multirow{5}{*}{ Age Groups } & $22-30$ & 7 & 5.5 \\
\hline & $31-40$ & 11 & 8.6 \\
\hline & $41-50$ & 51 & 39.8 \\
\hline & $51-60$ & 53 & 41.4 \\
\hline & $61-73$ & 6 & 4.7 \\
\hline \multirow{3}{*}{ Current Residence } & With parents & 6 & 4.7 \\
\hline & Private house & 60 & 46.9 \\
\hline & Flat & 62 & 48.4 \\
\hline \multirow{2}{*}{$\begin{array}{l}\text { Living } \\
\text { Environment }\end{array}$} & City/ Town & 40 & 31.3 \\
\hline & Country side & 88 & 68.8 \\
\hline \multirow{5}{*}{ Marriage } & Unwed & 13 & 10.2 \\
\hline & Married & 89 & 69.5 \\
\hline & In partnership & 9 & 7.0 \\
\hline & Divorced & 15 & 11.7 \\
\hline & Widowed, living with partner & 2 & 1.6 \\
\hline \multirow{3}{*}{ Marriage Nr. } & Unwed & 13 & 10.2 \\
\hline & Once & 102 & 79.7 \\
\hline & Twice & 13 & 10.2 \\
\hline \multirow{2}{*}{ Children } & I do not have children & 7 & 5.5 \\
\hline & I have children & 121 & 94.5 \\
\hline \multirow{4}{*}{ Parents’ Marriage } & Mother first, father first marriage & 116 & 90.6 \\
\hline & Mother first, father second marriage & 7 & 5.5 \\
\hline & Mother first, father other version of marriage & 3 & 2.3 \\
\hline & Mother second, father second marriage & 2 & 1.6 \\
\hline \multirow{3}{*}{ Level of Education } & Higher education & 123 & 96.1 \\
\hline & Master's degree & 3 & 2.3 \\
\hline & Currently a student & 2 & 1.6 \\
\hline \multirow{7}{*}{ Major } & Humanities & 22 & 17.2 \\
\hline & Arts sciences & 19 & 14.8 \\
\hline & Preschool pedagogy (from 1 to 7 ) & 18 & 14.1 \\
\hline & Primary school pedagogy (from 7 to 10 ) & 23 & 18.0 \\
\hline & Elementary school pedagogy (from7 to 16) & 17 & 13.3 \\
\hline & Sciences & 19 & 14.8 \\
\hline & Social sciences & 10 & 7.8 \\
\hline \multirow{2}{*}{ Job Position } & Headmaster & 7 & 5.5 \\
\hline & Teacher & 121 & 94.5 \\
\hline \multirow{3}{*}{$\begin{array}{l}\text { Teaching Subject } \\
\text { Group }\end{array}$} & Arts & 20 & 15.6 \\
\hline & Humanities & 33 & 25.8 \\
\hline & Preschool teacher (from 1 to 7 ) & 18 & 14.1 \\
\hline
\end{tabular}


Dombrovskis, 2021. Job Satisfaction: Analysis of Socio-Demographic Data Related to Job Satisfaction Among Teachers in the Vidzeme Region

\begin{tabular}{|c|c|c|c|}
\hline & Sciences & 46 & 35.9 \\
\hline & Social sciences & 8 & 6.3 \\
\hline & Headmaster & 3 & 2.3 \\
\hline \multirow{3}{*}{ My Nationality } & Latvian & 123 & 96 \\
\hline & Russian & 4 & 3.1 \\
\hline & Belarussian & 1 & .8 \\
\hline \multirow{5}{*}{$\begin{array}{l}\text { Father's } \\
\text { Nationality }\end{array}$} & Latvian & 114 & 89.1 \\
\hline & Russian & 9 & 7.0 \\
\hline & Belarussian & 2 & 1.6 \\
\hline & Ukrainian & 2 & 1.6 \\
\hline & Polish & 1 & .8 \\
\hline \multirow{4}{*}{$\begin{array}{l}\text { Mother's } \\
\text { Nationality }\end{array}$} & Latvian & 118 & 92.2 \\
\hline & Russian & 7 & 5.5 \\
\hline & Belarussian & 2 & 1.6 \\
\hline & Ukrainian & 1 & .8 \\
\hline \multirow{5}{*}{ Parents' Marriage } & Living together & 45 & 35.2 \\
\hline & Divorced & 15 & 11.7 \\
\hline & Father dead & 29 & 22.7 \\
\hline & Mother dead & 2 & 1.6 \\
\hline & Father and mother dead & 37 & 28.9 \\
\hline
\end{tabular}

Job satisfaction was ranked on the Likert scale, ranging from 1 ("very dissatisfied") to 10 ("very satisfied"). Data processing found that there were four larger satisfaction groups. "Dissatisfied" included data related to "Very dissatisfied," "Dissatisfied," and "Nearly dissatisfied.". "Average, but more dissatisfied" included "More dissatisfied than satisfied" and "Average, but a tendency to be dissatisfied," while "Satisfied" covered "Nearly satisfied," "Satisfied," and "Very satisfied."

Data processing and analysis were based on non-parametric statistical methods, because the cohort was not in line with a normal distribution of parameters. The author used descriptive statistical methods such as Crosstab and the Spearman rank correlation.

\section{Results}

These are the results of the general "Job satisfaction" cohort:

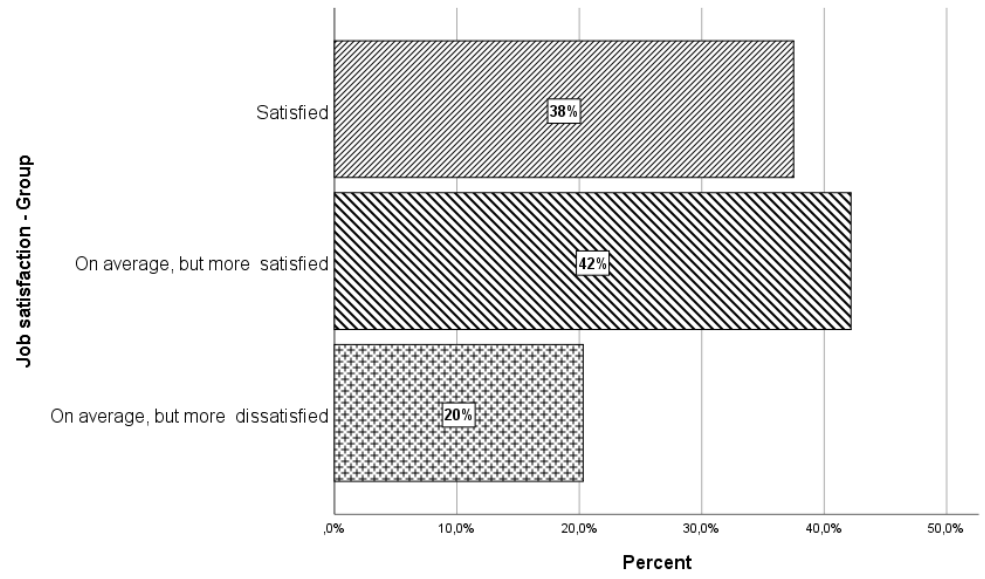

Figure 1 Teacher Job Satisfaction Groups 
The results show that $20 \%$ of respondents have an average level of dissatisfaction with their work, while the remaining $80 \%$ have an average level of satisfaction or satisfaction about their work. Because the data were collected at a teacher conference, it may be that the cohort tilted toward delegates who were interested in continuing their career. None of the respondents indicated that he or she was "dissatisfied" with the work.

A look at job satisfaction and age groups found no major links (rs (126) $=$ $.44, \mathrm{p}=.619$ ), though there are some positive linkage tendencies.

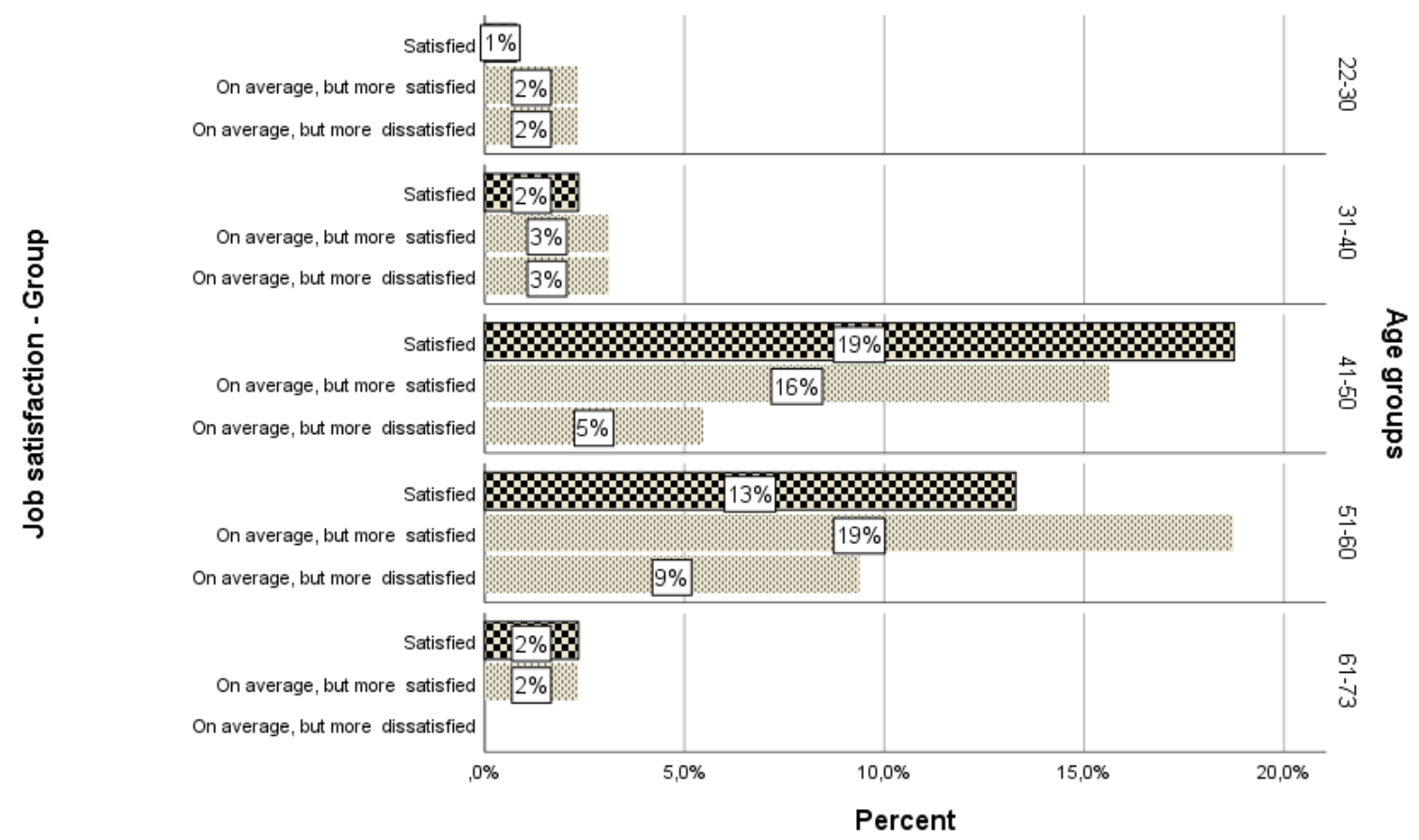

Figure 2 Job Satisfaction Divided by Age Group

A look at job satisfaction on the basis of age group (Figure 2) shows that the largest differences are found in the 41-50 and 51-60 age groups. Crosstab data analysis shows trends between the two indicators. When it comes to the internal data set of age groups, $11.5 \%$ of respondents from the 22-30 age group were more dissatisfied with their work, while the percentage for the 31-40 group was $15.4 \%$, it was $26.9 \%$ for the $41-50$ age group, and at a level of $46.2 \%$ in the $51-60$ group. None of the teachers from the 61-73 age group indicated dissatisfaction. A look at the indicators "Average, but more satisfied" and "Satisfied" shows a level of $5.6 \%$ and $2.1 \%$ in the $22-30$ group, $7.4 \%$ and $6.3 \%$ in the $31-40$ group, $37 \%$ and $50 \%$ in the $41-50$ group, $44.4 \%$ and $35.4 \%$ in the $51-60$ group, and $5.6 \%$ and $6.3 \%$ in the 61-73 group. There were no statistically meaningful links between age and job satisfaction $(\mathrm{rs}(126)=.44 ; \mathrm{p}=.619)$. 
Dombrovskis, 2021. Job Satisfaction: Analysis of Socio-Demographic Data Related to Job Satisfaction Among Teachers in the Vidzeme Region

Table 2 Job Satisfaction and Place of Residence

\begin{tabular}{|c|c|c|c|c|c|c|}
\hline \multirow{2}{*}{\multicolumn{3}{|c|}{$\begin{array}{l}\text { Soc.Dem.Factors / } \\
\text { Soc.Dem. Sub- factors }\end{array}$}} & \multicolumn{4}{|c|}{ Job Satisfaction } \\
\hline & & & $\begin{array}{c}\text { On average, but more } \\
\text { dissatisfied }\end{array}$ & $\begin{array}{c}\text { On average, but } \\
\text { more satisfied }\end{array}$ & Satisfied & Total \\
\hline \multirow{9}{*}{$\begin{array}{l}\text { Current } \\
\text { residence }\end{array}$} & \multirow{3}{*}{ With parents } & Count & 2 & 2 & 2 & 6 \\
\hline & & \% within Job satisfaction & 7.7 & 3.7 & 4.2 & 4.7 \\
\hline & & $\%$ of Total & 1.6 & 1.6 & 1.6 & 4.7 \\
\hline & \multirow{3}{*}{ Private house } & Count & 11 & 25 & 24 & 60 \\
\hline & & $\%$ within Job satisfaction & 42.3 & 46.3 & 50.0 & 46.9 \\
\hline & & $\%$ of Total & 8.6 & 19.5 & 18.8 & 46.9 \\
\hline & \multirow{3}{*}{ Flat } & Count & 13 & 27 & 22 & 62 \\
\hline & & \% within Job satisfaction & 50.0 & 50.0 & 45.8 & 48.4 \\
\hline & & $\%$ of Total & 10.2 & 21.1 & 17.2 & 48.4 \\
\hline
\end{tabular}

Analysis of the "Current residence" indicator found no statistically important links (rs (126) $=-.024, \mathrm{p}=.789$ ). Trends (Table 2) do not also speak to any distinct tendencies that would speak to some kind of link with the place where the teacher lives and the extent to which the teacher has job satisfaction.

A look at links between "Living environment" and "Job satisfaction" also found no statistically important links (42(126) =-.117; $\mathrm{p}=.189)$. There were also no linkage tendencies.

Next, there is the issue of "Marriage," which included the categories "Unmarried," "Married," "Partnership," "Divorced" and "Widowed, but living with partner". Here, again, no statistically important links, but if the five indicators are grouped into two - "Relationship" and "Alone," then there are linkage trends, but no statistically important links (rs (16) $=.059$; $\mathrm{p}=.509$ ). Crosstab shows that $35 \%$ of teachers who do not have a relationship have more of a tendency to be dissatisfied at work, while $65 \%$ of teachers with a relationship indicated that. The tendency of being more satisfied (85\%) and satisfied (77\%) with work is seen among teachers who have a relationship, while among those who do not, only $15 \%$ are satisfied at an average level, while $23 \%$ are satisfied.

Analysis of the "Number of marriages" and "Satisfaction with work group," $65 \%$ of respondents said that they were dissatisfied about teachers who had married just once, while $12 \%$ disliked those who were married several times. $23 \%$ of teachers who had never been married were dissatisfied with the internal group. Similar trends were seen in terms of average satisfaction or satisfaction with work. $7 \%$ of unmarried women had average satisfaction, as did $6 \%$ of the internal group. Among women married once, the figure was $83 \%$ and $83 \%$, while for women who had been married more than once, it was $9 \%$ and $10 \%$. These are trends, but they are not statistically important links ( $r s(126)=.112 ; \mathrm{p}=.208)$.

Next, there is the issue of links between "Satisfaction with the work group" and the issue of whether the respondents have children. 3\% of women with no children were more dissatisfied with their work, $2 \%$ were more satisfied, and only $1 \%$ were totally satisfied. Among teachers with children, $17 \%$ were more 
dissatisfied, $41 \%$ were more satisfied, and $37 \%$ were satisfied with their work. This has statistically important links ( $\mathrm{rs}(126)=.186$; $\mathrm{p}=.35)$.

There were no statistically important links when looking at the linkage between job satisfaction and the marriage model of parents ( $\operatorname{rs}(126)=.83$; $\mathrm{p}=.35$ ). Crosstab analysis shows that teachers whose parents had only been married once were more satisfied with work than teachers whose parents had married more than once. $34 \%$ of those who had parents who only married once said that they were satisfied with their work, while $38 \%$ were at an average level or more satisfaction, with only $21 \%$ saying that they are at an average level, but more dissatisfied with their work. Among those teachers whose parents had married repeatedly, 3\% were satisfied at an average level, and 5\% were more satisfied (there were no data about those who were dissatisfied).

Links between job satisfaction and siblings were recategorized into new groups because of the limited amount of data - "Only child," "Older brother," "Younger brother," "Younger sister," "Many brothers and sisters." There were no statistically important links here $(\mathrm{rs}(126)=.167 ; \mathrm{p}=0.59)$. Still, there were tendencies of linkage.

Table 3 Job Satisfaction and Siblings

\begin{tabular}{|c|c|c|c|c|c|c|}
\hline \multirow{2}{*}{\multicolumn{3}{|c|}{ Soc.Dem.Factors / Soc.Dem. Sub- factors }} & \multicolumn{3}{|c|}{ Job satisfaction } & \multirow{3}{*}{$\begin{array}{r}\text { Total } \\
21\end{array}$} \\
\hline & & & \multirow{2}{*}{$\begin{array}{c}\text { On average, but more } \\
\text { dissatisfied }\end{array}$} & \multirow{2}{*}{$\begin{array}{c}\text { On average, but } \\
\text { more satisfied }\end{array}$} & \multirow{2}{*}{$\begin{array}{c}\text { Satisfied } \\
6\end{array}$} & \\
\hline \multirow{10}{*}{$\begin{array}{l}\text { Sibling } \\
\text { s Rec }\end{array}$} & \multirow[b]{2}{*}{ Only child } & Count & & & & \\
\hline & & $\%$ of Total & 3.9 & 7.8 & 4.7 & 16.4 \\
\hline & \multirow{2}{*}{ Older brother/s } & Count & 5 & 8 & 6 & 19 \\
\hline & & $\%$ of Total & 3.9 & 6.3 & 4.7 & 14.8 \\
\hline & \multirow{2}{*}{ Younger brother/s } & Count & 5 & 11 & 8 & 24 \\
\hline & & $\%$ of Total & 3.9 & 8.6 & 6,3 & 18.8 \\
\hline & \multirow{2}{*}{ Younger sister/s } & Count & 5 & 9 & 6 & 20 \\
\hline & & \% of Total & 3.9 & 7 & 4.7 & 15.6 \\
\hline & \multirow{2}{*}{$\begin{array}{l}\text { Many brothers and } \\
\text { sisters }\end{array}$} & Count & 6 & 16 & 22 & 44 \\
\hline & & $\%$ of Total & 4.7 & 12.5 & 17.2 & 34.4 \\
\hline
\end{tabular}

Data in Table 3 show that teachers with several younger and older brothers and sisters show more satisfaction and dissatisfaction.

Data about job satisfaction and the level of education were not analysed in greater depth, because there was insufficient data in the cohort (123 respondents had a higher education, three had a master's degree, and two were students at the time of the study). 
Dombrovskis, 2021. Job Satisfaction: Analysis of Socio-Demographic Data Related to Job Satisfaction Among Teachers in the Vidzeme Region

Table 4 Job Satisfaction and Area of Science

\begin{tabular}{|c|c|c|c|c|c|c|}
\hline \multirow{2}{*}{\multicolumn{3}{|c|}{ Soc.Dem.Factors / Soc.Dem. Sub- factors }} & \multicolumn{3}{|c|}{ Job satisfaction } & \multirow[b]{2}{*}{ Total } \\
\hline & & & $\begin{array}{l}\text { On average, but } \\
\text { more dissatisfied }\end{array}$ & $\begin{array}{l}\text { On average, but } \\
\text { more satisfied }\end{array}$ & Satisfied & \\
\hline \multirow{14}{*}{$\begin{array}{l}\text { Studied } \\
\text { group of } \\
\text { science }\end{array}$} & \multirow{2}{*}{ Humanities } & Count & 6 & 11 & 5 & 22 \\
\hline & & $\%$ of Total & 4.7 & 8.6 & 3.9 & 17.2 \\
\hline & \multirow{2}{*}{ Arts \& sciences } & Count & 2 & 9 & 8 & 19 \\
\hline & & $\%$ of Total & 1.6 & 7 & 6.3 & 14.8 \\
\hline & \multirow{2}{*}{ Preschool pedagogy (from 1 to 7) } & Count & 5 & 9 & 4 & 18 \\
\hline & & $\%$ of Total & 3.9 & 7 & 3.1 & 14.1 \\
\hline & \multirow{2}{*}{$\begin{array}{l}\text { Primary school pedagogy (from } 7 \\
\text { to } 10 \text { ) }\end{array}$} & Count & 4 & 9 & 10 & 23 \\
\hline & & $\%$ of Total & 3.1 & 7 & 7.8 & 18 \\
\hline & \multirow{2}{*}{$\begin{array}{l}\text { Elementary school pedagogy } \\
\text { (from7 to 16) }\end{array}$} & Count & 4 & 7 & 6 & 17 \\
\hline & & $\%$ of Total & 3.1 & 5.5 & 4.7 & 13.3 \\
\hline & \multirow{2}{*}{ Sciences } & Count & 3 & 5 & 11 & 19 \\
\hline & & $\%$ of Total & 2.3 & 3.9 & 8.6 & 14.8 \\
\hline & \multirow{2}{*}{ Social sciences } & Count & 2 & 4 & 4 & 10 \\
\hline & & \% of Total & 1.6 & 3.1 & 3.1 & 7.8 \\
\hline
\end{tabular}

Data related to links between job satisfaction and the area of science were not statistically important $(\operatorname{rs}(126)=.134 ; \mathrm{p}=.130)$. Crosstab results (Table 4) show that the level of job satisfaction among teachers with various groups of science are quite comparable.

Links between job satisfaction and the job of the pedagogue (headmaster, teacher) had no statistically important linkages (rs(126) =.-.127; $=.153$ ). But there are trends to show that no headmaster had an average and more level of dissatisfaction, though $20 \%$ of teachers said so. Other job satisfaction aspects between these two categories of work are comparable.

Analysing data between subject group and job satisfaction, again, found no statistically important links (rs(126=.025; $\mathrm{p}=.778$ ).

Table 5 Job Satisfaction and Area of Teaching

\begin{tabular}{|c|c|c|c|c|c|c|}
\hline \multirow{2}{*}{\multicolumn{3}{|c|}{ Soc.Dem.Factors / Soc.Dem. Sub- factors }} & \multicolumn{3}{|c|}{$\begin{array}{l}\text { Job satisfaction } \\
\end{array}$} & \multirow[b]{2}{*}{ Total } \\
\hline & & & $\begin{array}{c}\text { On average, but } \\
\text { more dissatisfied }\end{array}$ & $\begin{array}{l}\text { On average, but } \\
\text { more satisfied }\end{array}$ & Satisfied & \\
\hline \multirow{8}{*}{$\begin{array}{l}\text { Subject } \\
\text { group } \\
\text { teach }\end{array}$} & \multirow{4}{*}{ Arts } & Count & 3 & 8 & 9 & 20 \\
\hline & & $\begin{array}{l}\text { \% within Subject group } \\
\text { teach }\end{array}$ & 15 & 40 & 45.0 & 100 \\
\hline & & \% within Job satisfaction & 11.5 & 14.8 & 18.8 & 15.6 \\
\hline & & $\%$ of Total & 2.3 & 6.3 & 7.0 & 15.6 \\
\hline & \multirow{4}{*}{ Humanities } & Count & 8 & 14 & 11 & 33 \\
\hline & & $\begin{array}{l}\text { \% within Subject group } \\
\text { teach }\end{array}$ & 24.2 & 42.4 & 33.3 & 100 \\
\hline & & \% within Job satisfaction & 30.8 & 25.9 & 22.9 & 25.8 \\
\hline & & \% of Total & 6.3 & 10.9 & 8.6 & 25.8 \\
\hline
\end{tabular}


SOCIETY. INTEGRATION. EDUCATION

Proceedings of the International Scientific Conference. Volume II, May $28^{\text {th }}-29^{\text {th }}, 2021.178-191$

\begin{tabular}{|c|c|c|c|c|c|}
\hline \multirow{4}{*}{$\begin{array}{l}\text { Preschool } \\
\text { teacher (from } 1 \\
\text { to } 7 \text { ) }\end{array}$} & Count & 5 & 8 & 5 & 18 \\
\hline & $\begin{array}{l}\text { \% within Subject group } \\
\text { teach }\end{array}$ & 27.8 & 44.4 & 27.8 & 100 \\
\hline & \% within Job satisfaction & 19.2 & 14.8 & 10.4 & 14.1 \\
\hline & \% of Total & 3.9 & 6.3 & 3.9 & 14.1 \\
\hline \multirow{4}{*}{ Sciences } & Count & 10 & 17 & 19 & 46 \\
\hline & $\begin{array}{l}\% \text { within Subject group } \\
\text { teach }\end{array}$ & 21.7 & 37.0 & 41.3 & 100 \\
\hline & \% within Job satisfaction & 38.5 & 31.5 & 39.6 & 35.9 \\
\hline & $\%$ of Total & 7.8 & 13.3 & 14.8 & 35.9 \\
\hline \multirow{4}{*}{ Social sciences } & Count & 0 & 5 & 3 & 8 \\
\hline & $\begin{array}{l}\text { \% within Subject group } \\
\text { teach }\end{array}$ & 0 & 62.5 & 37.5 & 100 \\
\hline & \% within Job satisfaction & 0 & 9.3 & 6.3 & 6.3 \\
\hline & \% of Total & 0 & 3.9 & 2.3 & 6.3 \\
\hline
\end{tabular}

Crosstab analysis of job satisfaction and subject area (Table 5) shows that there are no social sciences teachers who have an average and more dissatisfied level with work, while teachers who teach natural science subjects are the most satisfied or at an average, but more satisfied level.

No statistically important links between the teacher's nationality and job satisfaction $(\mathrm{rs}(126)=.008 ; \mathrm{p}=.927)$. Crosstab analysis does not indicate any possible tendencies of linkage.

Statistically important links were not found when analysing the nationality of the respondent's father and job satisfaction (rs (126)=-.014; p=.877), and crosstab analysis also did not show any trends of linkage. Comparable results related to the mother's nationality (rs (126=-0.54; p-.546), and here, again, crosstab does not show any tendencies of linkage.

No statistically important links between parent's marriage and job satisfaction (rs (126) $=-0.28 ; \mathrm{p}=.751$ ), and crosstab analysis showed no tendencies of linkage.

An examination of a cohort of 434 respondents with 132 men and 302 women led Bolin to argue that statistically meaningful effects on teacher job satisfaction relate to the age of teachers, the length of their experience and the subject that they teach. Bolin also analysed various dimensions of relationships, including the existence of siblings, as well as the age difference with brothers and sisters. Bolin did not, however, offer data about the link between these indicators and teacher job satisfaction (Bolin, 2008). Chirchir (2016) has also argued that gender and age have statistically meaningful links with job satisfaction. This study did not find statistically important links with job satisfaction, and that may be because of the size of the cohort. Bolin's cohort (2008) had 434 respondents, Chirchir's had 848, and this study had 128 respondents, all of whom were women (Chirchir, 2016). 


\section{Conclusions}

1. In the Amata, Priekuli, Ligatne, Pargauja, Rauna, Vecpiebalga, Jaunpiebalga and Cesis administrative districts in the Vidzeme region have $80 \%$ of teachers who are almost satisfied or fully satisfied with their work.

2. There are statistically meaningful links between job satisfaction and socio-demographic indicators such as whether the respondent had children. Teachers with kids were more satisfied with work than teachers who had none.

3. There were no statistically important links between job satisfaction and socio-demographic factors such as age, place of residence, a relationship or living alone, the number of marriages, the marriage model of parents (number of marriages) and the life model of parents at the time of the study, whether or not there are siblings, the level of education, the area of science that was studied, the topics that are taught, and the nationality of the teacher and her parents.

4. Significant trends related to job satisfaction apply to socio-demographic factors such as the relationship status of teachers, with those who were in a partnership tending to be more satisfied with their work that those who did not have a relationship and lived alone. There was also the issue of marriage. Teachers who had married once or had not married tended to be more dissatisfied with their jobs than teachers who had married several times. Teachers whose parents were only married once showed the tendency of being more satisfied with work than those whose parents had married several times. When it came to siblings, teachers with many brothers are sisters tended to be more satisfied their work, particularly if they were a "middle child," as opposed to an only child or an oldest or youngest child. These factors and their relationship with job satisfaction should be studied further with a larger cohort of respondents.

5. Additional research with more respondents will be needed to come up with recommendations on how to improve the job satisfaction of teachers. Data from this study are insufficient to produce such recommendations.

\section{References}

Arvey, R.D., Bouchard, T.J.Jr., Segal, N.L., \& Abraham, L.M., (1989). Job satisfaction: Environmental and Genetic Components. Jounal of Applied Psychology, 74 (2), 187-192. DOI:10.1037/0021-9010.74.2.187.

Bolin, F. (2003). A Study of Teacher Job Satisfaction and Factors That Influence It. Chinese Education and Society, vol. 40, no. 5, September/October 2007, 47-64. ISSN 10611932/2008. DOI 10.2753/CED 1061-1932400506. 
Cambridge Dictionary. (2020). Retrieved from: https://dictionary.cambridge.org/dictionary/ english/job-satisfaction.

Centrālās Statistikas Pārvaldes datu bāze. (2020). Skolotāju skaits vispārizglītojošajās skolās. Retrieved from: https://www.csb.gov.lv/lv/statistika/statistikas-temas/socialie-procesi/ izglitiba/tabulas/izg190/skolotaju-skaits-visparizglitojosajas-skolas

Chirchir, R. (2016). Demographic Factors and Job Satisfaction: A Case of Teachers in Public Primary Schools in Bomet County, Kenya. Journal of Education and Practice, Vol.7, No.13. ISSN 2222-288X.

Dewar, R., \& Werbel, J. (1979). Universalistic and contingency predictions of employee satisfaction and conflict. Administrative Science Quarterly, 24(3), 426-448.

Ebru, K. (1995). Job Satisfaction of the Librarians in the Developing Countries. 61st IFLA General Conference.

Eiropas Komisija. (2014). Darba apstākḷi: jauna aptauja parāda situācijas pasliktināšanos un lielas atškirības darba ñēmēju apmierinātībā. Retrieved from: https://ec.europa.eu/ commission/presscorner/detail/lv/IP_14_467

E-Klase. (2015). Iekalšanas laikmeta beigas. Kā mainās mācību paradigma? Retrieved from: https://www.e-klase.lv/aktualitates/zinas/iekalsanas-laikmeta-beigas-ka-mainas-macibuparadigma?id=10298

Graham, G.H. (1982). Understanding Human Relations. The Individual, Organizations, and Management. Science Research Associates. Chicago Inc.ISBN-139780574195203.

Hoppock, R. (1935). Job Satisfaction, Harper and Brothers, New York, 47.

Hughes, R.L., Gonnett, R.C., and Curphy, G.J. (2006). Leadership, Enhancing the Lessons of Experience (5). United States: McGraw Hill.

Izglītības klasifikācija. (2017). Noteikumi par Latvijas izglìtības klasifikāciju. Ministru kabineta noteikumi Nr. 322. Rīgā, Latvija (prot. Nr. 30 18. §). https://likumi.lv/ doc.php?id=291524

Judge, T.A., \& Watanab, S. (1994). Individual differences in the nature of the relation-ship between job and satisfaction. Journal of Occupational and organizational Psychology, 67, 101-107.

Lim, B.E. (2007). Study on the Job Satisfaction and Burnout among Medical Social Workers in Government Hospital in Malaysia. University Sains Malaysia. Master of Social Work.

Locke, E.A. (1976). The nature and causes of job satisfaction. In M.D. Dunnette (Ed.), Handbook of industrial and organizational psychology, 1297-1349. Chicago: Rand McNally.

Mullins, J.L. (2005). Management and organizational behaviour. Seventh Edition, Pearson Education Limited, Essex, p.700.

Organ, D.W., \& Near, J.P. (1985). Cognition vs affect in measures of job satisfaction. International Journal of Psychology, 20(2), 241-53.

Parasuraman, S. (1982). Redicting Turnover Intentions and Turnover Behaviour: A Multivariate Analysis. Journal of Vocational Behavior, 21, 111-121.

Peršēvica, A., (2013). Vidusskolu skolotāju apmierinātība ar darbu un tās mijsakarības ar izglītības kvalitāti. Promocijas darbs. Latvijas Universitāte, Pedagoǵijas, Psihologijas un Mākslas fakultāte. Rīga. Latvijas Universitāte.

Pool, S.W. (1998). The Relationship of Job Satisfaction with substitutes of Leadership, Leadership Behavior, and Work Motivation. Journal of Psychology, Vol.2., 1-25. DOI: https://doi.org/10.1080/00223989709603514. 
Dombrovskis, 2021. Job Satisfaction: Analysis of Socio-Demographic Data Related to Job Satisfaction Among Teachers in the Vidzeme Region

Ramanaidu, S.K. (2011). Uncovering the relationship between transformational leadership, Organizational Culture, Affective Commitment and Employee Performance: The Case of a Malaysian Educational Institution. Doctoral Dissertation, University of Newcastle, Faculty School of Business and Law, Graduate School of Business.

Rauf, M. (2012). Comparative Study of Organizational Commitment, Morale and Job Satisfaction of Subject Specialists and Lecturers Teaching at Intermediate Level. Unpublished Phd Thesis, p.199.

Spector, P.E. (1997). Job Satisfaction: Application, Assessment, Causes, and Consequences. California: Sage. Publications, Inc.

Suma, S. \&. Lesha, J. (2013). Job Satisfaction and Organizational Commitment: The case of Shkodra Municipality. European Scientific Journal, Vol 9, No. 17, 41- 51.

Vroom, V.H. (1964). Work and motivation, John Wiley and Sons, New York, p.99

Zeğele, E. (2008). Apmierinātība ar darbu kā organizācijas darba efektivitātes rādītājs. Biznesa psihologija, Februāris-marts, 32-35. https:/biznesapsihologija.lv/wp-content/uploads/ 2018/09/BP10.pdf

Zembylas, M. and E. Papanastasiou. (2006). Sources of teacher job satisfaction and dissatisfaction in Cyprus. Compare, Vol. 36, No. 2, 229 - 247. 